\title{
Arms up, Guns down. Analyzing the Clash between the Narratives of State and Media Actors on Light Weapons Control in Albania (2017)
}

\author{
Leida Ruvina \\ PhD Candidate at University of New York Tirana \\ Expert at the Albanian Ministry of Interior ${ }^{1}$
}

\begin{abstract}
The objective of this paper is to reflect on the relation between Communication studies and Security issues, by fitting particular developments into a larger scheme. In my hypothesis, public order and security can never be an exclusive duty of State Police alone, but a joint attempt for common goals. The institutional identity of the Police or Ministry of Interior itself is constituted by their purpose (why they exist), their brand (how they are perceived by others) and their culture (how members interact and work within them). Nevertheless, popular culture and mass media play an important role in effective institutional public communication. The challenge is to prevent, identify and manage incompatible or opposite messages promoted in the content managed by governmental and media authorities of a country, on the same topic, to the same audience, at the same time. By analyzing the behavioral communication and reflecting on how media exposures skew already available mental models to affect judgments, beliefs, and attitudes, I expect to provide a more complete framework on events occurred almost contemporarily, and to contribute in narrative-based persuasion strategies applied by governmental institutions in the future in Albania, suggesting Grunig's systemic approach of Public Relation. In the following work, I will construct the media narratives related to light weapons control in the Republic of Albania in 2017, and deconstruct the two incompatible narrative-based strategies in this regard. They demonstrate the need to harmonize the production or diffusion of public narratives and content on specific public order and security strategies.
\end{abstract}

1 Disclaimer: Views, thoughts, and opinions expressed in this article belong solely to the author, and not necessarily to the author's employer, organization, committee or other group or individual. Assumptions made within the analysis are not reflective of the official policy or position of any Albanian government entity. 
Keywords: public relations, crisis communication, public security, media narrative, cultural studies, Albania, ministry of interior, state police, weapons control

\section{Introduction}

\section{Crime and Twenty Years of News Content Shift}

Over the past twenty years, the human element is considered to make a story sexy, making the emotional side count, while the FACE formula, an acronym for Feelings Analysis/quick summary - Catastrophe, crime, corruption, color - Energy, has been applied by veteran television reporters. The view has been supported by Cohn (2007: 202) who reminds that before the shift in news content, reporting focused more on hard news, national policies and foreign affairs, rather than on human interest, health, crime, entertainment, scandals and celebrities; nevertheless the FACE formula may be taken as model for all media. As suggested by research from USC Annenberg School's Center for the Digital Future, in the United States, in 2007, experienced information-seekers ranked media and governments sites as more reliable than those published by individuals (Fearn-Banks, 2007: 45). The intermediation with public opinion is considered to be the expertise of public relations professionals.

The father of modern marketing, Philip Kotler (1999) defined the instruments of Public Relations as PENCILS, an acronym of Publication - Events - News - Community - Identity - Lobbying - Social responsibility. In terms of democratic theory, the public, meant as the average voter, was a "phantom" to the father of modern journalism and media researcher Walter Lippmann $(1920,1922,1925)$, who defended elitism as a distinctive intellectual option to populism, and described the ability that media had in defining what people consider important. The more salience on a topic by media, the more salience on that topic among undecided voters, noted also agenda-setting pioneers McCombs and Shaw (1972: 176-187). But media ability to define "not what to think, but what to think about" (Cohen 1963), is not universal. Cultivation theory (Gerbner 1990; 1998) recalls how mass media behavioral communication aims at social recognition through two order effects: on judgments first, and beliefs and attitudes second. In terms of social psychology, according to Olson (1998), the social environment plays a double role, by providing good examples and directing attitudes. Cultural context requires specific approaches to send a message. And the public opinion - or "what the people consider to be important" as defined by Maxwell McCombs (1981) - is both context and destination of the message.

"Advertise your business. Put on the appearance of business, and generally, the reality will follow. »

- P.T. Barnum (1855: 396). 
«This is not a secret press bureau. All our work is done in the open. We aim to supply news. This is not an advertising agency...Our plan is frankly, and openly, on behalf of business concerns and public institutions, to supply the press and public of the United States prompt and accurate information concerning subjects which it is of value and interest to the public to know about. »

- Ivy L. Lee (1906)

"The public relations counsel has a professional responsibility to push only those ideas he can respect, and not to promote causes or accept assignments for clients he considers antisocial. »

- E. L. Bernays (1947: 115-116).

Crime stories appear attracting. Although violence has not professed fans, a study made in 1996 by Pew Research Center found out that in the United States crime outranked in popularity sports, local government, religion, political news and entertainment; culture and arts, show-biz and financial news were the least interesting, a modest audience of $20 \%$ was driven by the situation in Bosnia, as $15 \%$ by the Congressional passage of a new law dealing with domestic terrorism (Pew Research Center 1996: 13-14). Twenty years hence technology has changed as the attraction points to sensational headlines or pictures drifting into traditional and new media as well. Narrative-based strategies related to crime go from the informationoriented journalistic reporting, to the persuasion-oriented awareness campaigns on governmental social media profiles, up to media coverage of infotainment-oriented sensational showbiz news. As Napoléon Bonaparte once said, "I fear three newspapers more than a thousand of bayonets" (Bernet 2004: 63). And that quote is a reminder that media coverage and advocacy is of particular importance in matters of public affairs.

\section{PR theoretical approaches to public security policies and strategies}

An advocating process in support or opposition to particular issues is expressed in no other ways than through narrative-based strategies, constructed by experts of communication. Their theoretical PR approach may vary from the rhetorical one of Robert L. Heath (2001), where the institutional advocacy includes all the parts interested in the discussion; to the critical Marxist approach supported by Marvin N. Olasky (1987), in which public relations constitute the inevitable attempt of hard powers to manipulate citizens' consciousness; and third, the more ethical and acceptable systemic model of James Grunig (1992), in which PR constitute the inevitable need of an organization to relate with its influent publics aiming at informing, changing behaviors, and avoiding risks of conflict by knowing and 
interpreting its publics' values and expectations even before defining its own specific objectives.

Other PR theoretical models differed from Grunig. In the '30s, the propaganda model of press agentry by the famed showman Phineas Taylor Barnum consisted in a oneway communication aimed to sell entertainment by fooling or capturing public's attention through "publicity" in its content rather than truth, considering the journalist as a tool (Barnum 1855: 394-399). In Ivy Ledbetter Lee's information model of public information (Lee 1906), the PR adviser produces and shares information to the intermediating journalist, aiming to influence public opinion in support to the objectives of the organization, through truth in its content. And in Bernays' scientific persuasion model of bidirectional asymmetric communication, social research on influent subjects - such as polls and surveys on focus groups - and the hearing or the feedback by persuaded intermediating opinion leaders, were a novelty that defined the PR expert by his competence in creating a dialogue. As Finn considered the image - meant by reputation - as a deliberate construction of no real relationship with the corporate identity (Finn 1961), Edward Louis Bernays also admitted that the very term "image" evocated the fact that PR and communication work on illusions rather realities (Bernays 1977), therefore, to convince the audience in a bidirectional asymmetric communication model had to be a duty of the PR adviser.

Following the definition in 1923 of his profession as PR adviser, a quarter-century after, Edward Barneys reminded that his profession had its own literature and training courses, that the major themes of a PR strategy emerge from opinion surveys, and that the public begins to act only when suggested by ideological, political or social idea, so only through the engineering of consent as "the very essence of the democratic process, the freedom to persuade and suggest" (Barneys 1947: 113).

But Grunig did not suggest a one-way communication aiming persuasion as feedback after a message is sent. Instead, according to his systemic model of symmetric bidirectional communication, the PR expert is an active interpreter between an organization and its influential publics, who permits the organization to know, understand and therefore incorporate values and interests of the latter in its own priorities and objectives before communication occurs, avoiding clashes, lacking trust or crisis communication in the future. Hereupon, the principal quality required for efficient PR should be the truth in the content information and the reciprocal understanding, in order to create a relation of quality and trust in the long run. It is not the instant persuasion, but the creation of a durable relation that matters.

Systemic models face different publics and different problems (Grunig \& Grunig 1996) and are far more ethically appropriate to corporate communication (Parsons 2005). The more truth, honesty, integrity, professionalism, respect, dedication and transparency are applied in a PR process, the more it may be considered ethical. The context within which public relations experts operate relates to honesty and integrity, 
as declared in the Code of Conduct guidelines by the UK's Chartered Institute of Public Relations (Green, 2010: 223), in the Code of Ethics by Public Relations Society of America (PRSA 2000), or in the Code of Venice by International Public Relations Association (IPRA 2009).

Public relations also apply to public administration. Once over with election campaigns, governmental PR should aim at the management of the public thing - or res publica - through consensus, not conviction. While governments rotate and their political programs change, objectives and missions of the Ministries almost remain the same. In a professional point of view, my assumption is that there is a need for a continuing dialog to elaborate, implement and evaluate public policies in relation to a complex social reality of influent publics. Reforms or achievements in public policies, new models for a crisis solution, proposals to change the legal framework etc., constitute the product that each ministry "sells" to the public opinion, but the citizen (differently from a client) is still the Sovran and the very raison d'être of that government. As long as the citizen is "client" but also the "boss", any Ministry requiring more than a mere spokesman will have an efficient PR adviser only when there is a relation established, maintained and reinforced between the Ministry and influent publics (citizens, opposition, international organizations, groups of interest, journalists, opinion leaders, NGO's, voters supporting or opposing the ruling party, and citizens with no party affiliation). That relation may help Ministries to propose new reforms or legal changes, or report their achievements in this regard.

Ministry of Interior and State Police are no exception. Just like corporate communication, their social success as institutions in charge of public order and security will aim at establishing a reputation, increasing visibility, sharing and consolidating the corporate social identity. The Albanian case is of particular interests in the implementation of PR theoretical models, narrative-based strategies and media studies.

\section{The Albanian context of guns control}

There is something comic in the arming of civilians in Albania during the last two decades. And it is better represented in the picture showing an armed reggae singer in 1997 and a media announcement by the State Police in February 2017.

In the black and white picture, Dashnor Diko - a citizen with no criminal recordings and well-known artist in the early '90s among Albanians - is shown into the sea, with the water up to his chest, a smile on his face, and an automatic gun in his raised arm. There are two reasons why the image is hilarious every time it is posted on social media. On one side there is the structural, physiological and behavioral environment of the supposed shooting: no murderer with a gun intended to kill goes swimming, and no one intended to take a swim brings a gun with him. On the other side, there is the ad hominem argument: Diko was a quiet guy, known among musicians for his songs and sense of humor, far from the sex, drugs, and rock and roll model, never 
mentioned, linked, neither perceived as linked to any kind of episode of violence. The pacifist singer adored Lennon and Marley so much that he dreamed to name "John" and "Bob" his sons if he ever had two - a dream later made true.

As Diko recently explained, that frame belonged to a day when he and friends actually cleaned the seashore up to 6 meters depth from 12 guns (27.al, 2017). That explanation is against all the narrative based on a heuristic processing model, in which mass media exposure skew already available mental models - the perception of increased violence in 1997 in Albania - to direct the public opinion towards what was supposed to be a rational interpretation of the image and its contextual representation. The supposed action of the subject in the picture was a misconception: Diko was putting weapons out of the water, not bringing an automatic gun into the sea and shooting up in the air for the fun of it.

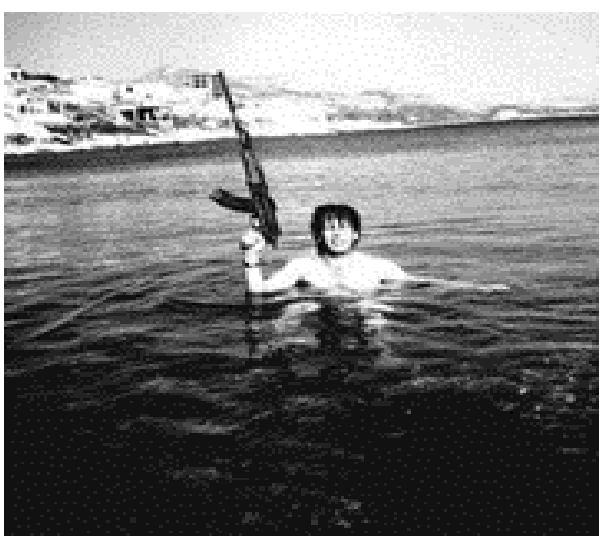

Picture:Dashnor Diko, an Albanian singer,cleaning the seashore from light weapons in 1997(Courtesy:27.aI)

Twenty years hence, there is still something comic in the fact that unregistered light or military weapons, collected during a voluntary surrender of firearms initiated by the Albanian Ministry of Interior in 2017, have included among others anti-tank mines and anti-aircraft missiles, held in a domestic environment for two decades (ASP 2017). And that visual frame serves as a reminder of a time of anarchy when it was possible to escape the collective madness following state collapse and the massive opening of weapon depots, to escape the spread of light or heavy weapons among civilians, and the shooting - up in the air for the fun of it or for a criminal purpose. It also reminds that a picture may be worth a thousand words, but media visual narrative of a context may misrepresent the truth, by transforming a good action for public safety into a dramatic misconception at worst, or ridiculous act at best.

There is also something tragic in the arming of civilians in Albania during the last two decades. It is reminded by the sons and daughters who survived the death of their dearest by intentional or accidental homicide, as the case in the southern Vlora, where a father working at the local government was shot during 1997 anarchy; in the 
northern Shkodra, when a mother drinking coffee in her home garden was hit by a blind bullet; or in central Tirana, where a teenager son was shot in a gang crossfire, while holding the line at the bread store, just a few days after celebrating Teacher's Day in Petro Nini High School. Testimonies and legacy still persist among the living, not just among press materials or official reports, where the true dimension of dramatic events is confirmed by statistics.

The 1,542 lives lost during 1997 only, stand as a reminder of a time of anarchy when the uncontrolled possession of weapons caused victims more than the previous six years period 1991-1996, and almost as much as the four years to come 1998-2001 (MoI 2016, January). In the Republic of Albania, during the period 1997-2017, about 10,000 citizens have died or were seriously injured due to weapons (MoI 2016, November). Along the two following decades, the year 2015 marked the fewest number of homicides since 1997, with 54 annual cases - a record actually broken in 2018 with only 51 cases of the criminal offense (ASP 2019, February). For the threeyear period of 2014-2016, statistics have shown a decline in the total number of intentional homicides. Referring to the graphics in the Annual Performance Report 2015 of the Albanian State Police and Ministry of Interior (MoI 2016, January), by comparing criminal indicators of the previous three years 2011-2013, gun theft have dropped by over $170 \%$, from 287 to 106 , and recorded cases of illegal weapons possession have increased by $29.3 \%$. During 2016 alone, $85.8 \%$ of illicit weapons possessions have been detected, for which an average of 3 people per day has been arrested. Notwithstanding, prison sentences and statistics are not enough without preventing the risks posed by small arms and light weapons.

In the Criminal Code (Law No.7895/1995), the Albanian legislation clearly defines several offenses related to the illicit use of firearms. ${ }^{1}$ Some legal changes have been

${ }^{1}$ Among them, sexual or homosexual assault under gun threat (Article 104), armed robbery (Article 140), rioting (Article 221), call to arms or to take the command unlawfully (Article 222), acts of terror (Article 230), manufacture of military weapons (Article 234), armed gang (Article 234/b), organization of unlawful gatherings and manifestations with the participation of armed people (Article 263), disturbing public peace (Article 274), manufacture and illegal possession of firearms and ammunition (Article 278), trafficking of weapons and ammunition (Article 278/a), illegal manufacture and illegal possession of hunting and sporting rifles (Article 280), training on unlawful manufacturing and use of weapons or other dangerous substances (Article 282/b), criminal acts committed by an armed gang or criminal organization (Articles 333-335). 
made in the fight against illicit firearms possession, use, and trafficking. From

Statistics on weapons collected in Albania during the two first amnesties (from 1997-June 2005)

\begin{tabular}{|c|c|c|c|}
\hline & Ammunitions & Explosives & Weapons \\
\hline $\begin{array}{c}\text { Looted } \\
\text { in 1997 }\end{array}$ & $839,310,038$ & $16,000,000$ & 549,775 \\
\hline $\begin{array}{c}\text { Collected: } \\
\text { March }\end{array}$ & $118,134,222$ & $1,539,828$ & 222,918 \\
$\begin{array}{c}\text { 1997 - } \\
\text { June 2005 }\end{array}$ & & & or \\
\end{tabular}

Source: MOI weapons collection unit, in Safeworld and CPDE (2015:114), and in Council of Ministers Decision No.50, dated Fehruarv 62.019 "On the Annroval of the Small Arms I.iaht

August 26, 2016, the illicit weapons possession Act came into force (Law No.82/2016, Article 2), approved with the latest amendments to the Criminal Code and its Article 278 which set out tighter measures in this context. ${ }^{1}$ Improved public order indicators and crime prevention were affected by three amnesties of the criminal offense Illegal Possession of Weapons, which managed to collect about half of the undeclared weapons stolen from state depots in 1997 - despite the fact that some were illegally trafficked out of Albania in the years 1997-1998 or have actually run out of use. ${ }^{2}$

${ }^{1}$ Respectively: Unauthorized possession of weapons, ammunition, and explosive substances in motor vehicles and public spaces is sentenced to 3-7 years in jail. Unauthorized use of military munitions as a criminal offense is punishable by a fine or up to 2 years. Unauthorized possession of weapons in the domestic environment is sentenced to 1-3 years. The detention of explosive weapons/materials in the domestic environment is sentenced to 1-4 years. Also, the production, purchase, sale, trading, and transportation of weapons, ammunition, explosives, and explosive weapons without proper permission, is sentenced to 5-10 years: a penalty up to 7-15 years when the criminal offense is committed in large quantities, in collaboration, more than once or with serious consequences. Last but not the least, counterfeiting, erasure, relocation or alteration of marks on weapons and ammunition, is punishable by 1-5 years of imprisonment.

2 The first amnesty (August 1998 - August 4, 2002) was based on Law No.8388, dated August 5, 1998 "On the Collection of Weapons and Military Ammunition". It was drafted by the Albanian Government that came out from the June 1997 elections and established the principles and methods for voluntary surrender of weapons, registration for a businessmen category, compulsory collection by police forces. A weapons collection facility was established with 250 police officers who, upon completion of the amnesty, were deployed and engaged in other police tasks. One million houses were visited, asking people to voluntarily surrender their weapons and ammunition, or sign a declaration of not possessing an illegal gun. The implementation of the second amnesty (April 10, 2003 - May 31, 2005) was based on Law No.9018, dated March 6, 2003 “On the collection of weapons, ammunition, and other combat equipment", while the addition of the amnesty article was specified in Law No.9017. It was accompanied by awareness-raising methods in schools, logistical support from UNDP, various investments in institutions or development projects etc. For the next 11 years, from $31^{\text {st }}$ 
As shown in a report on small arms and security in South-Eastern Europe by Safeworld and the Center for Peace and Disarmament Education (2015:114), MoI Weapons Collection Unit states that during the first two amnesties, from 1997 up to June $2005,40.5 \%$ of weapons looted from military bases have been returned. Last but not the least, over half million ammunitions, were collected during a third amnesty implemented between January and April 2017, with precisely 603 different firearms, 1,558 hand grenades and 580,634 various ammunition surrendered nationwide (CMD 2019:321).

Meanwhile, the legal framework of the Republic of Albania also defines the criteria to be met for a firearms license. Adopting their provisions with the EU directives, with the support of missions assisting the Albanian State Police such as ICITAP, PAMECA and the Albanian Helsinki Committee, Law No.74/2014 "On Arms" (Official Gazette No.126: 5775-5787) does not liberalize the right to keep and bear arms in Albania as does the $2^{\text {nd }}$ Amendment in the United States for example - but sanctions instead the firearms ownership right. ${ }^{1}$ Law No.72/2014 "On the Use of Firearms" (Official Gazette No.124: 5728-5729) - partially aligned with Council Directive 91/477 / EEC of 18 June 1991 "On the control of arms purchases and possession" of the Council of the European Union (Official Journal of the European Union L256: 51-58) - is compulsory for the employees of the Albanian State Police, for the Armed Forces of the Republic of Albania (when used for providing public order only in cases when police forces are unable to perform it), as well as for other subjects that are equipped with firearms on the basis of a special law. ${ }^{2}$

May 2005 until December 2016, there was no amnesty for weapons collection. In the third amnesty (January 14 - April 30, 2017), pursuant to Law No.141, dated December 22, 2016 "On Amnesty" and the Ministry of Interior (MoI) initiative \#AlbaniaWithoutWeapons, Community Policing Workers (SPZ) went door-to-door to inform and raise awareness on the handover of illegal weapons, controlling the territory on a chart-basis drawn up by local police, cooperating with local government units, educational, religious, civil society, and keeping a constant relation between Police and media on the results.

${ }^{1}$ Law No.74/2014 "On Arms" tightens criteria of owning a firearm, such as the minimum age of 22 years; evidence of psycho-physical health; drug testing; police and criminal records in the exercise of violent resistance to the police, blood feuds or domestic violence; payment of state and public administration's tax obligations; reliability; proof of theoretical-practical ability to recognize and use the weapon (authorization from Licensed State Police courses); prohibition, also for ASP, of military weapons for civil use - removing therefore Kalashnikov and TT pistol from circulation; shooting and administration of experimental cartridges by the State Police and its lab.The law definitely undermines the firearms ownership rights ex officio automatically and without any criterion, as permitted by the previous law to judges, MPs, and mayors. The law also defines the power prevalence for the use of weapons by State Police.

2 Law No.72/2014 "On the Use of Firearms" also tightens criteria of firearms use. Unlike the previous law, criterion define the objective degree of danger and firearm counterattack against the police forces, according to the principle of necessity and proportionality (the weapon will be used as the ultimate tool, in extremis, against anyone - including minors, women and the elderly - when all other means for the prevention or prohibition of illegal assault have been exhausted and when facing a high risk to the life of the police officer or any other citizen; the weapons' use as a means of warning or 
Despite the criteria set out in the legal framework for the license to arms possession and use, the Ministry of Interior considered necessary to undertake an initiative, named \#AlbaniaWithoutWeapons, concretized in one short-term amnesty for voluntary surrender and collection of illegal weapons from the hands of civilians. Briefly introduced in November 2016 through a similar UN campaign launched and implemented by MoI, named "Don't shoot but love" (SEESAC 2016), the amnesty bill passed all legal steps: from its drafting in the meeting of the Council of Ministers, to the invitation for public consultation on MoI official website, the review in the National Security Commission, the voting in the Assembly, the declaration of Law 141/2016 "On Amnesty" (Official Gazette 2016 No.255: 25513-25515) and its entry into force fifteen days later. Article No.7 corresponds to the legal foundation for the third amnesty to firearms possession from $14^{\text {th }}$ January to $30^{\text {th }}$ April 2017, after which punishment for the criminal offense is to 15 years.

Illicit weapons possession has been treated differently by main political parties. All the three amnesties for the criminal offense, aiming at the voluntary surrender and collection of firearms (the first on August 1998 - August 2002, the second on April 2003 - May 2005, the third on $14^{\text {th }}$ January - 30 ${ }^{\text {th }}$ April 2017), have actually been drafted, adopted and implemented by the Albanian Left or the Socialist Party. Regarding the Right, as publicly confessed to a journalist and former-PDK MP in Kosova, the former President of the Republic and historic DP leader Sali Berisha states that him and his Democratic Party opened weapon depots in Middle and Northern Albania, "aiming to balance the already armed opponents and its supporters, as well as arming the Kosovo Liberation Army" (Buzhala 2017). Statements by the Right Democratic Party that suggested a purchase of illicit firearms voluntarily handed, may have consequently contributed in a public hope for potential profit and hesitation for such surrender. It must be noted that in this regard, also the Socialist MP of Shkodra Region, Paulin Sterkaj, suggested twice the remuneration of donated laptops - never cash - in exchange of handed arms (Panorama 2013, Java News 2017). In the political discourse, episodic call to arms, actually a criminal offense to Article 222 of the Criminal Code, have been also publicly made by the Albanian Right (Balkanweb 2016, Tema 2018).

According to the Albanian Institute of Statistics INSTAT, there were 1.8 homicides per 100 thousand inhabitants in Albania in 2015. The indicator was 2.5 times higher than the EU average the same year $(0.7$ homicides per 100 thousand inhabitants, according

dissemination of protests is definitively prohibited; it is forbidden to kill animals with weapons except when by any other veterinary means it becomes impossible to ban an animal posing a risk to the life of the citizen). Types of weapons for which permission is granted include: Sports Weapons (for easy or targeted sports shooting), Hunting Guns (for passion or need, according to the law), Collection Weapons (fully or partially disabled), Pistols (ex officio, for prosecutors investigating serious crimes, criminal organization, organized crime, terrorism, narcotics, trafficking in human beings, domestic crime, and murder of police officers - as defined in the DCM by Berisha government following the killing of the Head of Shijak Police Station 2011-2012. 
to EUROSTAT). Although a small country of 2,870,324 people, Albanian official estimates were twice as many as the EU countries. The last decade marked a decreasing trend until 2018 marked the lowest record, with 51 intentional homicides, as defined by Articles 76, 78, 79 of the Albanian Criminal Code (ASP official statistics).

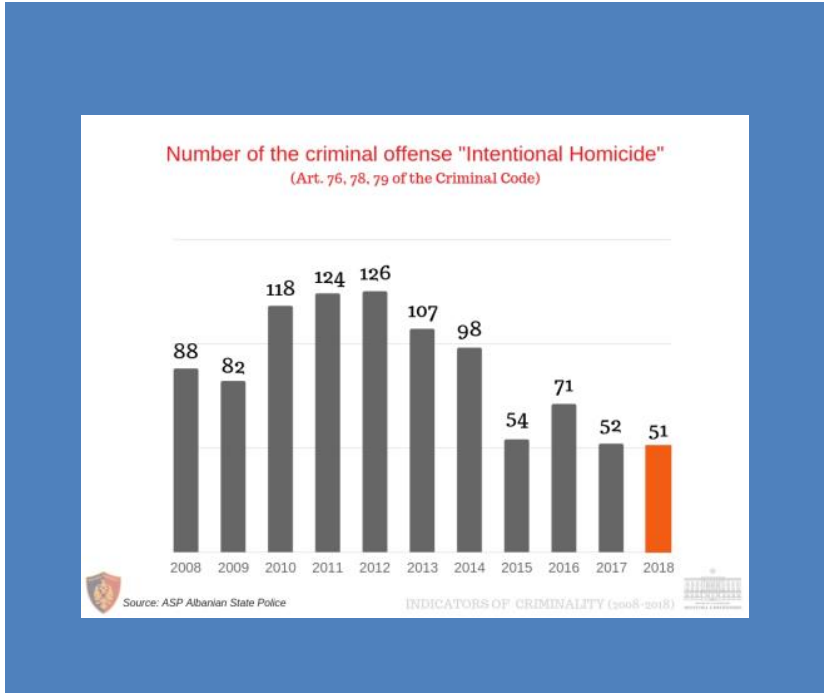

Attention on this issue is still paid by the Albanian government, in the framework of the adoption of the Regional Roadmap for a sustainable solution to the illegal possession, misuse, and trafficking of Small Arms and Light Weapons and their ammunition in the Western Balkans by 2024, part of the Berlin process. The proliferation restriction of Small Arms and Light Weapons (SALW) is confirmed to be part of civilian disarmament policies, promoted through regular campaigns by the United Nations and European Union projects (such as UNDP SEESAC for South Eastern Europe, and PAMECA). In the European Union where Albania aims to integrate, the right to life is defined by the European Convention of Human Rights (ECHR 2018: Article 2). In special regards to prevention, in 2017 Ministry of Interior developed "Albania Without Weapons" campaign, managed on social media, covered by new and traditional media.

\section{4. \#AlbaniaWithoutWeapons campaign of MoI and PAMECA (2017)}

The awareness campaign for voluntary surrender of weapons and ammunition was supported through Community Policing, a new theoretical concept in the Albanian Ministry of Internal Affairs (MoI) aiming at law enforcement approval, not by force but in close cooperation between Police officers and the community they serve. To that date, the partnership with the public and this quality assurance service had been introduced by the "Digital Commissariat App", the mega-event "You Are My Hero" at the Pediatric Hospital on $1^{\text {st }} J u n e$ 2016, the Fair "Open Day with Police" on 7-8 th June 
2016 or $14^{\text {th }}$ March 2017, or the business card field distributing of the unique Emergency Number "112" on late June - mid July 2016.

From a PR expertise point of view, the following suggestions were given and applied (Ruvina 2017). The situation analysis and media fact-checking confirmed that intentional or accidental homicides and firearm-related death rate are news and make news, in focus of public attention. The raising awareness up to $30^{\text {th }}$ April 2017 and the increased long-term credibility were defined as purpose/objectives of the PR Plan. As strategy (approach and effort focus) was suggested the advocacy through a creative campaign, that would inform on the legal initiative and amendments, as well as on potential incidents from weapons possession in the domestic environment; that would raise awareness and convince the public for the lawful and right thing to do; and would also promote the Ministry, State Police and international partners. The promotion element was in focus this time, since, in the first similar campaign (Mos gjuaj por duaj 2016), the specific Facebook and Instagram pages missed to remind MoI as initiator or UNDP SEESAC as supporter, as well as to interact with followers few people commented and there was no Crisis Management of haters or skeptic vox pops. ${ }^{1}$

On this ground were defined the tactics, or how the strategy would have been implemented. For the initiative \#AlbaniaWithoutWeapons realized by the Ministry of Interior and supported by the EU program PAMECA from 29 th March to 30 th April 2017, the PR expert at MoI Communication Directorate provided creative elements of the campaign such as: Advertising Copy or text for the leaflet and the VIP spot script; psychological negotiation for a real-life testimony of a firearm incident; photo essay from the backstage of the spot based on the true story, later used for Timeline Photos; a Content Strategy and Crisis Management for the specific Facebook page (Shqiperia Pa Arme 2017); native-ad article, etc. The Content Management signed an innovation in the relationship with the public: each of the FB comments and public suggestions had feedback. Legal references explained simply and the tag for local police stations

\footnotetext{
${ }^{1}$ Earlier, a first awareness campaign on the risks of illegal possession and misuse of firearms in Albania was "\#MosGjuajPorDuaj or "Don't Shoot But Love" implemented from 14th November $-14^{\text {th }}$ December 2016, financed by the European Union in the framework of the Common Foreign and Security Policy, with the support of the United Nations Development Program (UNDP) and the Central and Eastern European Office for Small Arms and Light Weapons (SEESAC), implemented by the Ministry of Internal Affairs in cooperation with the MANIACARD Freecard Advertising Media Agency. In 2010, MANIACARD was awarded 'Cannes Act Tribute' Prize at Cannes Film Festival, as favorite free card campaign with the postcard "Stop construction at the expense of nature". During \#dontshootbutlove campaign, their tactics in public spaces included Guerrilla Marketing (a worldwide strategy initially conceived in 1984, focused on unconventional low budget tactics that bring maximum results) and the use of leaflets, posters, social media etc. As to the Facebook Community Page, among others it published 3 live-streams of the event presentation, 1 professional spot, 1 amateur recording of VIP testimonials, 1 GIF presentation, photos from the Minister's meeting at local level, shared albums from the Minister's meetings with high school students in front of a staged crime scene, media articles on firearm crimes and Police calls to voluntary surrender them.
} 
was opted to inform but also promote the relationship between the State Police and the community. Also, tagging institutions such as MoI, ASP, EU Delegation in Tirana or PAMECA, the press agencies and newspapers that covered the initiative, or the VIPs who agreed to become part of a spot, aimed at promoting the initiative itself to the followers of the above, increasing visibility. Different tactics aimed to reach different publics: hard copy leaflets for local community inhabitants; two professional spots on MoI official channel on YouTube and content management on a specific Facebook page for online communities in Albania and abroad; native-ad for Albanian-speaking press and online media. ${ }^{1}$ Preliminary information to MoI and PAMECA was provided through a scrutinous fact-checking of media articles, police statistics and subsequently comparative elaboration, the legal framework through years and political implications in the process of spreading and collecting weapons since 1997.

Identifying - and successfully dealing with - public resistance to the given message, as defined by Festinger (1962) has been part of the PR work for this campaign. One counterargument noticed in Facebook comments, for example, was the risk posed by the supposed "Army surrender": this misunderstanding was quietly but firmly clarified since the focus of the campaign was disarming civilians, not soldiers of the Army. Another counterargument was the rationalized need of weapons for hunting in remote areas or for self-defense: this was also simply but sufficiently clarified as the law permits licensed gun possession but under more severe criteria. A further skepticism by militant or politically independent public was the risks of dealing with state propaganda, as persuasive narratives are often discounted as manipulative and unethical according to Dahlstrom and Ho (2012): this was also overcome by an ethical communication and a management of the specific Facebook Page by the campaign's name, instead of "Ministry of Interior". To Drozd, Lehto, and Oinas-Kukkonen (2012: 165) motivation and engagement through dialogue support, feedback, and counseling by credible communicators is confirmed as crucial to gaining the desired behavioral change. In this case, while it was made clear that the campaign's official FB profile was managed by the institutional representative, by interacting with a country ("Albania Without Weapons") rather than a political party affiliated "Ministry", provided higher positive mental response, fewer chances to cognitive dissonance - and to dealing with them through political biasing. At this first level, new information was provided, with the amnesty deadline and local police stations to be contacted for the voluntary weapons surrender. This was the law and the lawful thing to do.

At the next level, storytelling at social media was considered the antidote to this resistance. Its persuasive power aimed to reach the audience by identifying, transporting it into the narrative engagement, with the purpose of dispelling misconceptions, and integrating new information in a sound manner from a psychological cognitive behavior perspective, as suggested by Meisel and Karlawish

${ }^{1}$ Actually published online on Balkanweb, Gazeta Express, Ora News, Lexo.al, Shqiptarja.com, Gazeta Blic, Arbresh.info, Java News, and print on Shqiptarja.com). 
(2011). Visual and narratives were involved as support materials. Since real stories on screen have resulted more persuading than fiction on the very same information (Kimmerle and Cress 2013), the power of narrative persuasion was invested in the testimony of a woman, appearing at the end of the spot where the story her husband and minor son was narrated.

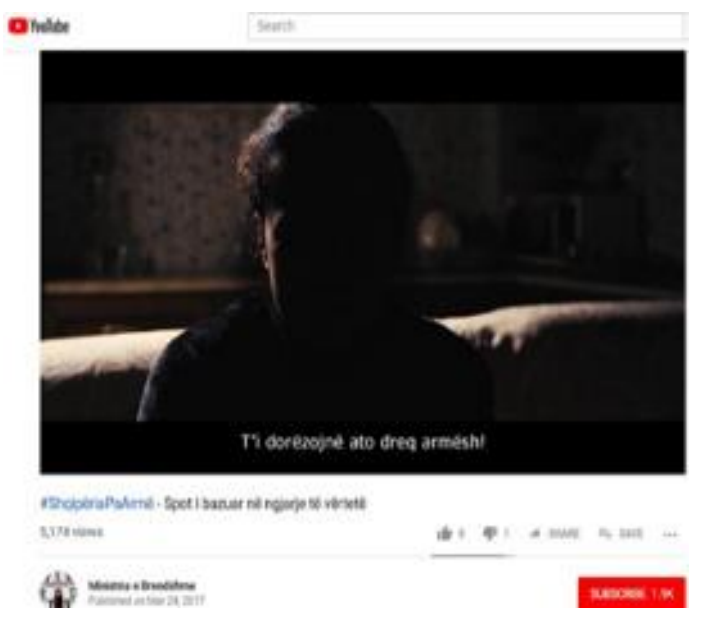

Picture: Frame from the spot based on a true story, with a final real-life testimony for \#AlbaniaWithoutWeapons. (C2017 Ministry of Interior, with the support of PAMECA (EU program). Marketing agency: Connext. Production: Nilor. (Source: MoI Official YouTube Channel)

Actors in the first spot staged a real story occurred in Vlosh village, Fier, on $1^{\text {st }}$ July 2016, when a farmer was accidentally shot to death by his 8-years old boy. The narrative integrated the new information (on the amnesty initiative and its deadline) with the social bond of identification. As suggested by Feiereisen, Wong, and Broderick (2013), visual mental simulations and verbal analogies into a familiar framework help the ones missing the proper mental framework to better understand the benefits of the behavioral change. The spot, based on a true story, aired on YouTube on 24th March 2017 and reached 5,174 views. The woman's final genuine call reminded that the story is real, that what happens to someone can happen to everyone, and that the public policy of voluntary firearms surrender is not only legal but also legitimate and the right thing to do.

By respecting an ethical communication, MoI had previously asked her and the family of the deceased written permission for granting the right to use in a spot their personal history - although previously published by national media. Then the MoI PR expert negotiated and convinced the initially hesitant widow to give her own testimony, respecting the privacy. The anonymity of the final real-life testimony was granted through proper techniques, such as darkening the image for face recognition or avoiding real names or locations in the subtitles. By recognizing underlined 
cognitive processes, the successfully established relation and the created dialogue was with the real witness first, and the online Facebook audience later.

A Ministry's cause or governmental policy of public interest becomes interesting when supported and promoted by a charismatic Minister. This also constitutes the risk of incarnating that cause with the Minister himself, and of limiting the media attention strictly to the period in which that Minister holds the office although the campaign promoting that cause has just begun or isn't over yet. Unfortunately, the spot based on the true story was first published on the Facebook account of former Minister of Internal Affairs and only subsequently on the official FB Page or website of the Ministry, hence the main media narrative considered it more like part of a personal initiative of Mr.Tahiri rather than of the Ministry itself. Once the Minister left the office on $11^{\text {th }}$ March 2017, this campaign promotion on official MoI channels, as well as its media coverage, decreased markedly.

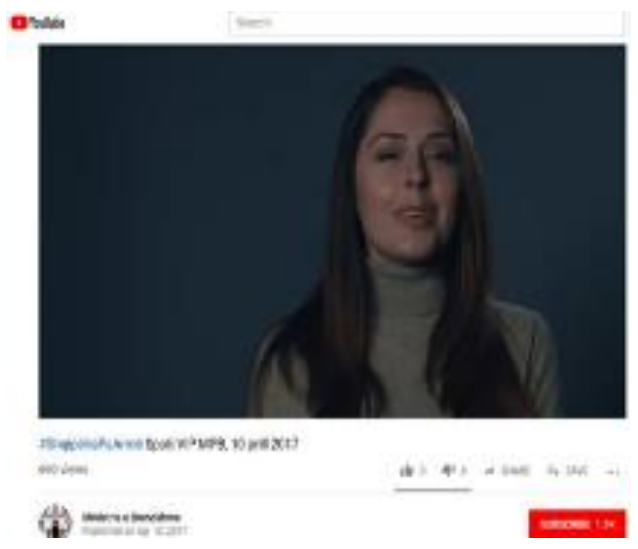

Picture: VIP version of the spot for the awareness campaign \#AlbaniaWithoutWeapons and frame for the video (C2017 Ministry of Interior, with the support of PAMECA (EU program). Marketing agency: Connext. Production: Nilor. (Source: MoI Official YouTube Channel)

The second spot featuring VIPs aired through social media and YouTube on $10^{\text {th }}$ April 2017 and reached only 690 views. Political events and the transitory phase at the Ministry of Interior also made impossible its introduction or launch on TV through a guest appearance on morning shows or prime-time debates, as well as its promotion in Anglophone media for further advocacy.

The initiative of illicit firearms collection was set among 2017 top priorities for MoI and State Police by the then-Minister of Interior Tahiri, whose all-inclusive approach for public awareness met also school and religious communities. ${ }^{1}$ The same priority

1 MoI (2017) "Komunitetet fetare kanë rol themelor në çarmatosjen e mendjes dhe të shpirtit", awareness meeting in Dajç, Shkodër, February 6, 2017, published at the official MoI website. MoI 
was confirmed by the following Minister, Fatmir Xhafaj. The third amnesty in this regard resulted in the collection of 1,341 firearms, 439,415 cartridges, 1,138 cartridge-clips, 1,377 offensive and defensive grenades, 1,038 firefighters, 1,057 detonators, 74 artillery and anti-tank shells, 45 TNT blocks, 11 mines, 2 anti-aircraft missiles, 1 flamethrower, and 1 box of poisonous substances (ASP 2017, April). On 18 th April 2017, the Albanian Parliamentarian Commission of National Security approved the 8-month extension of the amnesty deadline up to 31 December, as proposed by the Secretary of the Commission and Socialist MP, Pirro Lutaj. Unfortunately, the approved draft-bill was never to be adopted during the VIII legislation, which ended with the last plenary session on $4^{\text {th }}$ May amid tensions and boycott by the opposition. Two weeks later, on $18^{\text {th }}$ May an agreement for a technical government was reached between Premier Rama and the DP leader Basha, followed by the preparations for parliamentarian elections of $18^{\text {th }}$ June. \#AlbaniaWithoutWeapons was no longer in the agenda-setting that year.

\section{Gun possession and the clashing narratives of mass media}

Gerbner's Cultivation theory recalls the effects that behavioral communication has on judgment, beliefs, and attitudes of the public opinion. Grunig's systemic approach of Public Relations actually applied during the crisis management of the social media campaign \#AlbaniaWithoutWeapons, covered a public security policy on this cultivation basis, aiming to inform, convince and promote what was legal and right.

Differently from the messages sent by the Ministry of Interior, to the same Albanian public opinion, almost at the same time, the same topic - on illicit weapons possession and use - was covered differently by a different content strategy applied by mainstream media. The narrative on some Albanian Rap bands is the typical case worthy of particular mention. Hard and soft drugs apart, weapons have been a subject explicitly promoted in the narrative related to the lifestyle or work of some Albanian rap singers. The proper strategy matched to automatic guns as supposed "hedonistic objects" has been their visual mental simulation - while, as noted by Feieresien, Wong, and Broderick (2013), verbal analogies better match to "utilitarian objects".

In the Albanian music industry, communicating a weapon on the screen has never been a struggle. First, during Communism, the gun has been associated with the antiFascist and anti-Nazis' resistance in times of war, proudly represented in movies, novels or songs. Later on, from 1997, the gun has been perceived as a symbol of the anti-State anarchy in times of peace, widely reported on national or international news. In the case of explicit content, the Albanian Broadcasting Code suggests the proper warning and time schedule in audiovisual media. This cultural environment and social brain may help to put the weapon media narrative in the proper context.

(2017) “Të ndihmojmë këdo që angazhohet dhe ka vullnet për të refuzuar dhunën e armët”, awareness meeting in Pjetër Budi High School, Burrel, Dibër, February 7, 2017, mb.gov.al. 


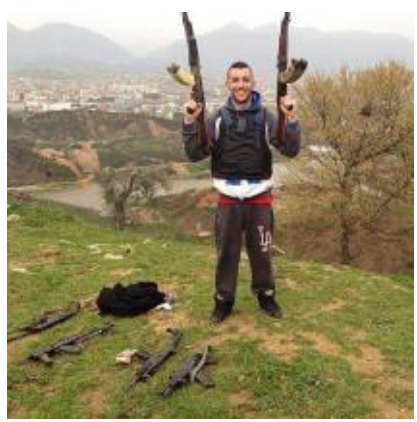

Picture: Arkimed Lushaj a.k.a Stresi, Albanian Rapper (Courtesy: Lajmi.net 2016)

Narratives on Rap singer known as "Stresi", can be the right case to be considered. During 2010-2017, media storytelling mainly focuses on his criminal records. It starts with his unpaid fines in Belgium and a conviction for extortion or blackmail against the founder of a private art school in Tirana; passing through public intoxication, illegal possession of weapons and disobedience to the police order during a Halloween night in the Albanian capital; his posting on social media a Christmas tree made of Cannabis; his escape jumping from the $2^{\text {nd }}$ floor of the Police Department and his following posts on social media against "dictators" and a possible asylum seeking; his photos on Instagram posing with guns, drugs and girls; up to his public reaction against the Minister of Interior who called artists for action against the promotion of violence on music videos, "as long the law permitted such freedom of expression" Stresi noted. Hence, the media storytelling on Stresi focuses on his personal character as loved by parents, wife, mother-in-law, other rappers, and even youth - as shown in episodic banners in the 2019 students' protests in Tirana.

Stresi is no isolated case. He has published a national symbol of the eagle transformed into a double-headed Cannabis plant, also into two pistols. In the last case, the symbol belonged to a Rap band London-based of Albanian nationals, named Hellbanians, promoted on Stresi's Official YouTube channel. Collaboration between Stresi and Hellbanians resulted also in a song entitled "GTA". Joking through the wordplay of the acronym for "Grand Theft Auto", the famous action-adventure video game series released in 1997, the refrain also called for "Gati tana armët" or literally All Guns Ready. Hellbanians, founded by Vinz, are actually known to the British media narrative as an important gang of Albanian nationals involved from UK's premier sex traffickers to kingpin cocaine dealers, reaching 115,000 followers on Instagram and 13,000 on Facebook until their pages were taken down on November 2018 for showing off drugs, money stacks, and guns (Argonathrpg 2017; The Sun 2017; Express 2018; The Guardian 2019; The Sun 2019). 


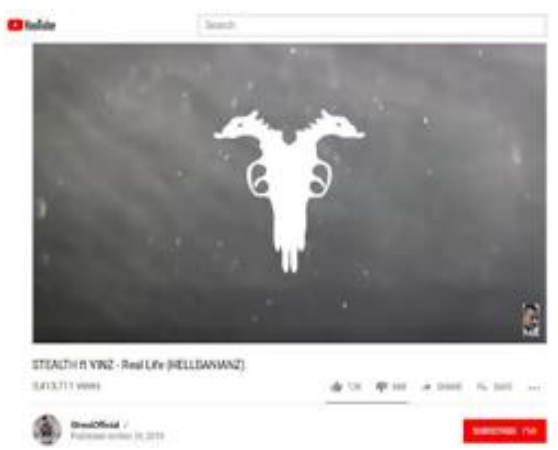

Picture: The premiere of Hellbanianz's "Real Life" explicit lyrics video, as posted on StresiOfficial YouTube Channel, on Albanian National Liberation Day, 29th November 2015, with over 3.4 million views.

In violation to the Albanian "Broadcasting Code for Audiovisual Media" (AMA 2017), the content of such songs and similar official videos on music channels incite hatred, intolerance, discrimination or justify violence among citizens; they contain elements of extreme violence; their broadcasting do not respect the time limit schedule 22:00 - 06:00 to prevent the mental or moral development of children from watching or listening; and as impropriate content which can harm children they are broadcasted without being preceded by an acoustic warning or identified by the presence of a visual symbol throughout their duration. In such a context, their broadcasting on TV networks or YouTube in general, as well as the intensive interviews and TV guest schedules of singer Stresi in particular, easily reach the overall public, building so a benevolent narrative towards Rappers of Albanian nationality with criminal recordings in Albania or Europe, as role models to be followed - or to be perceived as acceptable, promoting the illicit as the right thing to do. On weapons, this narrative obviously clashes with the one by the Ministry of Interior. Does argumenting change perception anyway?

\section{PR implications in the incongruity between crime indicators and public perception}

Barney's limits to persuasion should take into consideration that the public isn't always rational. Back in the late 2010s, the once acclamation "Facts are sacred" made by The Guardian's editor C.P.Scott, takes a whole different meaning in the fake-news era, where facts are spread in an unethical order, resulting in manipulation rather than information management, compromising truth itself.

And the simple truth just does not constitute a sufficiently convincing argument. In 2015 for example, the White House has reported that U.S. President Obama was seeking advice from social scientists such as psychologists to combat global warming: an executive order was issued instructing federal agencies to use behavioral science when developing programs to address rising temperatures and other policies, and a Social and Behavioral Sciences Team of psychologists, sociologists, and behavioral 
economist tested methods that might get people to act differently, since not all people are rational (Scientific American 2015). Another recent poll has shown that only 18\% of Republicans would support President Trump's impeachment if evidence of his collusion with Russia to win 2016 presidential election would be provided, while $63 \%$ wouldn't care (YouGov \& the Economist 2019). Thus, evidence and reason per se are not convincing arguments for making decisions.

On one side, crime shapes the public's sense of the state of their nation, and therefore of its future. If the national optimism gap was to be the dependent variable, the independent variable that helps explain it, without doubt, is crime and its public perception. Albania and the U.S. are two cases worthy of mention.

Referring to Gallup World Poll "Desire to emigrate”, for the 2013-2016 period Albania ranked $3^{\text {rd }}$ worldwide in terms of its citizens' highest desire to emigrate, after Sierra Leone with the Ebola outbreak and Haiti, followed by two other African states in conflict such as Liberia and Congo, and Syria ranked at the 9 th position: $56 \%$ of Albanians declared themselves as potential migrants, a percentage more than doubled compared to $36 \%$ in the previous poll edition conducted in 2010-2012 (Esipova, Ray and Pugliese 2017). As official Albanian sources pointed out that the year 2016 actually marked a decrease in the number of emigrants leaving the country from 41,000 in 2015 to 33,000 in 2016, and that economic reasons were the main impetus of emigration since the biggest groups of Albanian communities living abroad actually consist of economic emigrants, family members of economic migrants and students (Albanian Ministry of Interior 2017:5), Gallup also identified the wish to escape chronic high unemployment rates in Albania - just like in Italy - as the main reason why citizens wish to leave their country. The perceived economic push factor for migration was confirmed.

However, in matters of perceived security, according to Gallup's Report Law and Order Index Worldwide 2016, Albania ranked with a 79 index score, preceding Greece with 78, Macedonia 75 and Bulgaria 72 (Gallup August 2017: 6-7). A year later, Law and Order Index Worldwide 2017 ranked Albania with a lower perceived security index of 78, or the last in the Western Balkans, preceded by Serbia 82, Bosnia and Herzegovina 80 and Montenegro 79 - nevertheless performing a higher perceived public security than Bulgaria with 77 and Greece with 74 index score (GALLUP June 2018:7). As Gallup Law and Global Order Index provide leaders with an update on the progress made towards achieving the UN Sustainable Development Goals "Promoting Fair, Peaceful and Inclusive Societies", it also highlights those countries who need immediate change in security terms, where Albania is included.

Pessimism cases linked to the public perception of law and order are spread worldwide, in developing countries as well as in a democratic superpower. A few months before the robbery of Albanian army depots, in the United States on January 1997 a special Pew Research Center survey, conducted in conjunction with "State of the Union", revealed that three national problems in the U.S. such as crime (61\%), 
drugs (64\%) and low moral and ethical standards (62\%) were increasing in severity relate to moral and social decline according to over $60 \%$ of survey respondents; half believed there was a deteriorating quality of public schools (52\%), while in regards to political reforms $49 \%$ had the perception that America was losing ground in its efforts to fight political corruption:

«...Perceptions of a nation overwhelmed by moral and social problems are strongly linked to pessimism about the country's future. By a margin of 74\% to 54\%, pessimists are more likely than optimists to believe that crime is becoming a worse problem nationally. Crime is the one concern found to be driving pessimism among all major political subgroups, including those who voted for Clinton, those who voted for other presidential candidates, and those who decided not to vote at all...». (Pew Research Center for the People \& The Press, 1997).

On the other side, subjective perceptions of crime may not relate to the objective progression of criminality indicators. As noted by Pew Research (2019), for the 19932015 period the growing percentage of public perception's crime rate, or people saying there is more crime in the U.S. than a year ago, as reported by Gallup, was at odds with reality and the actually decreasing violent crimes per 1,000 persons age 12 and older, as shown by Justice Bureau of Statistics. The media narrative on crime, and PR implications in crisis management, in my opinion fill that gap between perception and reality.

\section{Conclusions and recommendations}

First, the shift from individual to collective or corporate identity affects governmental public relations. In my view, Kotler's instruments of Public Relations known with the acronym of PENCILS (Publication - Events - News - Community - Identity - Lobbying - Social responsibility) may be used by every community, company, institution or enterprise, regardless of the fact that the product they are "selling" is national news, a political party, a private education, a mobile phone, a croissant, oil fuel for cars, clothes for humans, food for pets, a football game, or a religion. In this regard, I do consider State Police and the Ministry of Interior as public institutions which may and should apply these instruments ethically, through truth, honesty, integrity, professionalism, respect, dedication and transparency as in corporate communication. I strongly believe that the return of the individual to a position of accountability improves the quality of the public dialogue, as the collective identity emphasizes the group and devalues the individual. There is no unique homogeneous public opinion; there are different influencing publics. Nevertheless, public relations or PR must be opened to hear and offer a space for relating with individuals that are not easily labeled a priori as supporters or opponent to an issue, but may instead represent a champion of the real population involved in a free public exchange of ideas. 
Second, public order and security can never be an exclusive duty of State Police alone, but a joint attempt for common goals. The institutional identity of the Police or the Ministry of Interior itself is constituted by their purpose (why they exist), their brand (how they are perceived by others) and their culture (how members interact and work within them). Notwithstanding, popular culture and mass media play an important role in effective institutional public communication. Rather than merely reporting reality, Media (both traditional such as the television, or the new media such as website profiles of newspapers, blogs, and social media profiles) constitute a resource for information, persuasion, and entertainment, encouraging unlawful acts and behaviors through the unethical promotion of particular actors. The challenge is to prevent, identify and manage incompatible or opposite messages promoted in the content managed by governmental and media authorities of a country, on the same topic, to the same audience, at the same time.

By analyzing the behavioral communication and reflecting on how media exposures skew already available mental models to affect judgments, beliefs, and attitudes, I provided a more complete framework on events occurred almost contemporarily, aiming to contribute to narrative-based persuasion strategies applied by governmental institutions in Albania in the future. Assuming that Gerbner's Cultivation Theory may be partially applied to explain particular political and social realities, an appropriate model for future solutions may be found in Grunig's systemic approach of Public Relation and its application on PR in public policies and during crisis management.

In this paper I attempted to construct the media narratives related to light weapons control in the Republic of Albania in 2017, and to deconstruct the two incompatible narrative-based strategies in this regard, respectively one supporting the Ministry of Interior's campaign (named "Shqipëria Pa Armë / Albania Without Weapons", in collaboration with PAMECA, managed in social media and covered by new and tradition media) - and another promoting law violation and gun possession through mass media coverage and advocacy of specific actions and actors from the show business and their deliberate messages in audiovisual commercial products.

In conclusion, media and cultural studies applied to a public campaign managed on social media by the Albanian Ministry of Interior, demonstrate the need to harmonize the production or diffusion of public narratives and content on specific topics of interest in matters of public order and security strategies.

\section{References}

[1] Bernays, E. L. (1928) Propaganda. New York: Routledge.

[2] Bernays, E. L. (1923) Crystallizing Public Opinion. New York: Liveright.

[3] Bernays, E. L. (1947) "The Engineering of Consent", in The Annals of the American Academy of Political and Social Science, 250(1), 113-120. 
[4] Barneys E. (1977) “Down With Image, Up With Reality”, in Public Relations Quarterly,22(1), 12-14.

[5] Barnum, P.T. (1855) The Life of P. T. Barnum written by himself. New York: Redfield.

[6] Chartered Institute of Public Relations (1963) "Code of Conduct", London.

[7] Cohen, B.C. (1963) The Press and Foreign Policy. Institute of Governmental Studies, University of California.

[8] Cohn, R. (2007) The PR Crisis Bible. How to take charge of the media when all hell breaks loose. Lexington: BookSurge Publishing.

[9] Dahlstrom, M. and Ho, Sh. (2012) "Ethical Considerations of Using Narrative to Communicate Science", in Science Communication 34. 592-617.

[10] Drozd F., Lehto T., Oinas-Kukkonen H. (2012) "Exploring Perceived Persuasiveness of a Behavior Change Support System: A Structural Model", in Bang M., Ragnemalm E.L. (eds) Persuasive Technology. Design for Health and Safety. PERSUASIVE 2012. Lecture Notes in Computer Science LNCS Vol.7284, 157-168. Berlin, Heidelberg: Springer.

[11] Fearn-Banks, K. (2007) Crisis Communication. A casebook approach. $3^{\text {rd }} \mathrm{ed}$. New York: Routledge.

[12] Feiereisen, S., Wong, V. \& Broderick, A.J. (2013) "Is a picture always worth a thousand words? The impact of presentation formats in consumers' early evaluations of really new products (RNPs)", in Journal of Product Innovation Management, 30(S1), 159-173.

[13] Festinger, L. (1962) “Cognitive dissonance”, in Scientific American, 207(4), 93-107.

[14] Heath, R. (2001) Handbook of Public Relations. Thousand Oaks, CA: Sage Publications.

[15] Gerbner, G. (1990) "Epilogue: Advancing on the path of righteousness (maybe)", in Signorielli, N. and Morgan, M (eds), Cultivation Analysis: New Directions in Media Effects Research, Newbury Park, CA: Sage, 249-262.

[16] Gerbner, G. (1998) "Cultivation analysis: An overview", in Mass Communication and Society Vol.I, 175-194.

[17] Green, A. (2010) Creativity in Public Relations. $4^{\text {th }}$ edition. London: CIPR, Kagan Page.

[18] Grunig J.E. (1976) “Organizations and Public Relations: Testing a Communication Theory" in Journalism and Communication Monographs No.46, Texas.

[19] Grunig J.E. (1992) Excellence in Public Relations and Communication Management. Hillsdale, New Jersey: Lawrence Erlbaum Associates.

[20] Grunig J.E. (2005) Il grande edificio e il suo constante arredamento. Quarant'anni di ricerca sulle relazioni pubbliche come funzione manageriale strategica. New York: Institute for Public Relations.

[21] Grunig J.E. and Grunig L.A. (1996) Implications of Symmetry for a Theory of Ethics and Social Responsibility in Public Relations. Paper presented to the 
Public Relations Interest Group, Chicago, IL: International Communication Association.

[22] Grunig J.E. and Hunt T. (1984) Managing Public Relations. New York: Holt Rinehart Winston.

[23] Habermas, J. (1990) Storia e critica dell'opinione pubblica. Roma-Bari: Laterza.

[24] IPRA International Public Relations Association $(1961,2009)$ "Code of Venice". London.

[25] Kimmerle J. and Cress, U. (2013) "The effects of TV and film exposure on knowledge about and attitudes toward mental disorders", Journal of Community Psychology 41(8), 931-943.

[26] Kotler, P. (1999) Il marketing second Kotler. Milano: Il Sole 24 Ore.

[27] Lee, I. (1906) “Declaration of Principles", as quoted by Sherman Morse "An Awakening in Wall Street: How the trusts, after years of silence, now speak through authorized and acknowledged press agents", in The American Magazine, vol. 62, September 1906: p.460.

[28] Lippmann, W. (1920) Liberty and the News. New York: Harcourt, Brace and Howe Company.

[29] Lippmann, W. (1922) Public Opinion. New York: Harcourt, Brace and Howe Company.

[30] Lippmann, W. (1925) The Phantom Public. New York: Harcourt, Brace and Howe Company.

[31] Maio, G.R. and Olson, J.M. (1998) "Attitude dissimulation and persuasion", in Journal of Experimental Social Psychology, 34(2), 182-201.

[32] McCombs, M.E. (1981) “The agenda-setting approach”, in Nimmo, D. \& Sanders K.R. (1981). Handbook of Political Communication, London, UK and Beverly Hills, CA: Sage, 121-141.

[33] Meisel, Z. F. and Karlawish, J. (2011) "Narratives vs evidence-based medicine - And, not or". in JAMA Journal of the American Medical Association, 306(18), 2022-2023.

[34] Olasky, M. (1984) "Roots of Modern Public Relations: The Bernays Doctrine", in Public Relations Quarterly, Winter, 29(4), p.25.

[35] Olasky, M. (1987) Corporate Public Relations: A New Historical Perspective.New Jersey: Lawrence Erlbaum Associates.

[36] Parson, P. (2005) L'etica nelle relazioni pubbliche. Milano: Il Sole 24 Ore.

[37] PRSA Public Relations Society of America (2000). "PRSA Code of Ethics". New York.

[38] Semetko, H.A., Blumler J.G, Gurevitch, M., Weaver, D.H. and Barkin, S. (1990). The Formation of Campaign Agendas: A comparative analysis of party and media roles in recent American and British Elections. NY-London: Routledge Communication Series.

[39] Windahl S., Signitzer B. and Olson, J.T. (1998) Progettare la comunicazione strategica. Milano: FrancoAngeli. 


\section{INTERNATIONAL REPORTS}

[1] Commission of European Communities (2001) Green Book: Promoting a European frame for corporate social responsibility. Brussels.

[2] Gallup (2017 June), cited in Esipova, N, Ray, J. \& Pugliese A. (2017). "Number of Potential Migrants Worldwide Tops 700 Million", Gallup World Poll, June 8, Washington DC. Retrieved online on February 28, 2019, https://news.gallup.com/poll/211883/number-potential-migrantsworldwide-tops-700-million.aspx.

[3] Gallup (2017 August) "2017 Global Law and Order Report”, August, Washington D.C. Retrieved online on February 28, 2019, https://news.gallup.com/reports/214607/gallup-global-law-order-report2017.aspx.

[4] Gallup (2018 June) "2018 Global Law and Order Report”. Washington DC.

[5] Gramlich, J. (2016) "Voters' perceptions of crime continue to conflict with reality". Fact-tank analysis. November 16, Pew Research Center Website, Washington DC. Retrieved online on February 28, 2019, http://www.pewresearch.org/fact-tank/2016/11/16/voters-perceptionsof-crime-continue-to-conflict-with-reality/.

[6] Gramlich, J. (2019) “5 facts about crime in the US". Fact-tank analysis. January 3. Pew Research Center Website, Washington DC. Retrieved online on February 28, 2019, http://www.pewresearch.org/facttank/2019/01/03/5-facts-about-crime-in-the-u-s/.

[7] Pew Research Center (1996) "TV News Viewership Declines. Fall off greater for young adults and computer users". Report. May 13. Washington DC. Retrieved online on February 28, 2019, http://www.pewresearch.org/wpcontent/uploads/sites/4/legacy-pdf/127.pdf. See also "Other Important Findings", Media release, May 13, online http://www.peoplepress.org/1996/05/13/other-important-findings-12/.

[8] Pew Research Center (1997) "The Optimism Gap Grows. Politics, Morality, Entitlements Sap Confidence". Report. January 17. Washington D.C. Retrieved online on February 28, 2019, http://www.pewresearch.org/wpcontent/uploads/sites/4/legacy-pdf/115.pdf.

[9] Pew Research Center (2016) "A Divided and Pessimistic Electorate. Voters skeptical of progress in many areas - even jobs - since 2008". Report. November 10. Washington DC. Retrieved online on February 28, 2019, http://www.people-press.org/2016/11/10/a-divided-and-pessimisticelectorate/.

[10] Ruvina, L. (2017) "Plani PR dhe foto-ese për fushatën \#ShqipëriaPaArmë" (trans. PR Plan and Photo-Essay for \#AlbaniaWithoutWeapons Campaign), Communication Expert, Internal report to the Communication Directorate, Ministry of Internal Affairs; $1^{\text {st }}$ March, Tirana; Unpublished. Last update on $16^{\text {th }}$ May 2017. 
[11] Safeworld and CPDE Center for Peace and Disarmament Education (2015, December) "Turning the Page. Small arms and light weapons in Albania", report on small arms and security in South Eastern Europe, p.114.

[12] YouGov \& the Economist Poll, March 3-5, 2019: 54-57. In Mathews, K. (2019) "Stop trying to convince Republicans Trump is a criminal - they do not care", March 9, Care2.com.

\section{OFFICIAL SOURCES}

[1] AMA (2017) "Broadcasting Code of Audiovisual Media Services", Decision of AMA Audiovisual Media Authority no.228, dated December 12th: Albania. Retrieved online on March 10th, 2019 at http://ama.gov.al/wpcontent/uploads/2018/05/Kodi-i-Transmetimit-p\%C3\%ABr-MedianAudiovizive.pdf

[2] ASP Albanian State Police (2017) "Policia e Shtetit: Vijon masivisht dorëzimi vullnetar i armëve" (Transl. "Massive voluntary surrender of weapons goes on"), April $4^{\text {th }}$. Official website asp.gov.al. Retrieved online on February $28^{\text {th }}$, 2019, https://www.asp.gov.al/index.php/drkm-diber/17-shqip/lajmet-efundit/11476-policia-e-shtetit-vijon-masivisisht-dorezimi-vullnetar-iarmeve.

[3] ASP Albanian State Police (2019, February) “Analizë e punës së Policisë së Shtetit për vitin 2018" (Annual Performance Report of the State Police for 2018), February $9^{\text {th }}$. Official website asp.gov.al. Retrieved online on February $28^{\text {th }}$, 2019, https://www.asp.gov.al/index.php/275-slideshow-home/14971analize-e-punes-se-policise-se-shtetit-per-vitin-2018.

[4] Council of the European Union (1991) "Council Directive 91/477/EEC of 18 June 1991 on control of the acquisition and possession of weapons", in Official Journal of the European Union, Series L, no.256, of 13.9.1991, pages 51-58, as amended by Directive 2008/51 / EC, in Official Journal of the European Union, Series L, no. 179, dated July 8 ${ }^{\text {th }}, 2008$, pp. 5-11.

[5] Council of Ministers Decision No.50, dated February 6th, $2019^{\text {"Për miratimin }}$ e Strategjisë për Kontrollin e Armëve të Vogla, të Lehta, Municioneve dhe Eksplozivëve 2019-2024 dhe të Planit të Veprimit 2019-2021" (On the Approval of the Small Arms, Light Weapons, Ammunition and Explosives Control 2019-2024 and the Action Plan 2019-2021), in Official Gazette No.13, February 8th 2019 , Tirana: Qendra e Botimeve Zyrtare, p.321. Retrieved online on February 28, 2019, http://www.qbz.gov.al/botime/fletore_zyrtare/2019/PDF-2019/132019.pdf.

[6] Council of Europe \& European Court of Human Rights "European Convention of Human Rights, European Court of Human Rights. Council of Europe. F67075 Strasbourg. Retrieved online on April 30th, 2017, https://www.echr.coe.int/Documents/Convention_ENG.pdf.

[7] ECHR European Court of Human Rights (2018) Guide on Article 2 of the European Convention on Human Rights, Council of Europe, December 31. 
ECHR Publication. Retrieved online on April 30th 2017 , https://www.echr.coe.int/Documents/Guide_Art_2_ENG.pdf.

[8] Law No.7895/1995 “Kodi Penal i Republikës së Shqipërisë” (Criminal Code of the Republic of Albania), Article no.278, Official website of the General Prosecutor's Office www.pp.gov.al. Retrieved online on February 28, 2019, http://www.pp.gov.al/web/kodi_penal_2016_1033.pdf . For the English version, see also the unofficial translation at http://rai-see.org/wpcontent/uploads/2015/08/Criminal-Code-11-06-2015-EN.pdf.

[9] Law No.72/2014, dated July 10, 2014 "Për përdorimin e armëve të zjarrit" (On the Use of Firearms), in Official Gazette No.124, August 8, 2014, Tirana: Qendra e Botimeve Zyrtare, pp.5728-5729. Retrieved online on February 28, 2019, http://www.qbz.gov.al/botime/fletore_zyrtare/2014/PDF-2014/1242014.pdf.

[10] Law No.74/2014, dated July 10, 2014 "Për armët" (On Arms), in Official Gazette No.126, August 11, 2014, Tirana: Qendra e Botimeve Zyrtare, p.5775-5787. Retrieved online on February 28, 2019, http://www.qbz.gov.al/botime/fletore_zyrtare/2014/PDF-2014/1262014.pdf.

[11] Law No.82/2016 “Për disa ndryshime në Ligjin Nr.7895 datë 27.01.1995” (On some amendments on Law No.7895 dated January 27, 1995, as amended), Article no.2, in Official Gazette No.151, August 11, 2016, Tirana: Qendra e Botimeve Zyrtare, p.1171. Retrieved online on February 28, 2019, http://www.qbz.gov.al/botime/fletore_zyrtare/2016/PDF-2016/1512016.pdf.

[12] Law No.141/2016 dated December 22, 2016 "Mbi dhënie amnistie" (On amnesty), in Official Gazette No.255, December 30. Tirana: Qendra e Botimeve Zyrtare, pp.25513-25515. Retrieved online on February 28, 2019, http://www.qbz.gov.al/botime/fletore_zyrtare/2016/PDF-2016/2552016.pdf.

[13] MoI Albanian Ministry of Interior (2016, January) “Policia Që duam” (The Police We Want), booklet, as published in " 2015 , viti historik i rezultateve pozitive të Policisë së Shtetit", media statement, January 5. Official website www.mb.gov.al [online]. Retrieved online on February 28, 2019, https://mb.gov.al/2016/01/05/2015-viti-historik-i-rezultateve-pozitive-tepolicise-se-shtetit/.

[14] MoI Albanian Ministry of Interior (2016, November) "Fushatë ndërgjegjësuese kundër armëmbajtjes pa leje 'Mos gjuaj, por duaj”, Minister's speech, November 15. Official website www.mb.gov.al. Retrieved online on February 28, 2019, https://mb.gov.al/2016/11/15/fushatendergjegjesuese-kunder-armembajtjes-pa-leje-mos-gjuaj-por-duaj/.

[15] MoI Albanian Ministry of Interior (2016). Ftesë për Konsultim Publik të projektligjit "Për dhënie amnistie". December 9. Official website of MoI. Retrieved online on April 30, 2017 on MoI official website 
http://www.punetebrendshme.gov.al/al/legjislacioni/konsultimipublik/projektligj-per-dhenie-amnistie\&page $=1$.

[16] MoI Albanian Ministry of Interior (2017) "Albania-Migration Profile 2016". Tirana: Official website of the Ministry of Interior and State Police. Retrieved online on February 28, 2019, https://mb.gov.al/wpcontent/uploads/2018/02/Profili_i_Migracionit_2016_Eng.pdf.

[17] Mol Albanian Ministry of Interior (2017, April) "Amnistia për armët, Komisioni i Sigurisë: Të shtyhet deri në 31 dhjetor", April 18. Official website of MoI. Retrieved online on April 30, 2017, https://mb.gov.al/newsroom/lajme/amnistia-per-armet-komisioni-isigurise-te-shtyhet-deri-ne-31-dhjetor.

[18] Parliament (2016) Review in the National Security Commission. December 20. Official website of the Parliament. Retrieved on February 28, 2019, https://www.parlament.al/wp-content/uploads/2016/12/RaportAmnistia-Dhjetor-2016.pdf.

[19] Parliament (2016) Voting in the Assembly of the Law 141/2016 "On Amnesty". Official website parlament.al. Retrieved on April 30, 2017, https://www.parlament.al/wp-content/uploads/2016/12/ligj-nr.-141-dt.22.12.2016.pdf.

[20] President of the Republic (2016) "Presidenti Nishani dekreton shpallje ligji nr. 141/2016" (President Nishani decides law announcement no. 141/2016). Official website president.al. Retrieved on April 30, 2017,http://president.al/en/presidenti-nishani-dekreton-shpallje-ligji-nr$1412016 /$.

[21] Prime Minister Office (2016, December) "Projektligje të miratuara në mbledhjen e Këshillit të Ministrave, datë 07 Dhjetor 2016" (Draft-laws adopted at the meeting of the Council of Ministers, dated 07 December 2016), December 7. Official website kryeministria.al. Retrieved online on February 28, 2019, https://www.kryeministria.al/newsroom/projektligjete-miratuara-ne-mbledhjen-e-keshillit-te-ministrave-date-07-dhjetor-2016/.

[22] SEESAC (2016) “Don't Shoot but Love” Stop illicit use of firearms before it is too late. November 15. Official website seesac.org. Retrieved online on April 30, 2017, http://www.seesac.org/News-SALW/Dont-Shoot-but-Love-Stopillicit-use-of-firearms-before-it-is-too-late/.

[23] Tahiri, S. (2017) “2016, vit i konsolidimit të punës së Policisë në luftën kundër kriminalitetit", Minister speech at the Annual Performance of MoI and ASP, January 4, MoI Official website. Retrieved online on April 30, 2017, https://mb.gov.al/2017/01/04/2016-vit-i-konsolidimit-te-punes-sepolicise-ne-luften-kunder-kriminalitetit/.

[24] Tahiri, S. (2017) “Gjirokastër, Tahiri: Dorëzimi vullnetar i armëve, prioriteti ynë për 2017" (Tahiri: Voluntary surrender firearms, our priority for 2017), January 17. Official website of MoI. 
[25] Xhafaj, F. (2017) “Ministri Xhafaj: Detyra prioritare, t'i konsolidoj arritjet dhe t'i çoj përpara", March 27. MoI official website. Retrieved online on April 30, 2017,, https://mb.gov.al/te-rejat/lajme/ministri-xhafaj-detyra-prioritare-ti-konsolidoj-arritjet-dhe-t-i-coj-perpara\&page $=14$.

\section{MAGAZINES}

[1] Bernet, A. (2004) "La presse à la botte, la culture au pas", in Historia Thématique 'Napoléon, empereur ou dictateur', no.92, Novembre-Décembre 2004, p.63. Retrieved online on February 28, 2019, https://www.historia.fr/la-presse-\%C3\%A0-la-botte-la-culture-au-pas.

[2] Lehmann, E. and Wire, C. (2015) "Obama Seeks Psychological Help with Climate Change. The social sciences could help combat global warming", in Scientific American, September 16. Retrieved online on February 28, 2019, https://www.scientificamerican.com/article/obama-seeks-psychologicalhelp-with-climate-change/.

\section{NEWS AGENCIES}

[1] Argonathrpg.eu (2017) "Hellbanianz Crime Family / Vinz". Retrieved online on April 30, 2018 www.argonathrpg.eu/index.php?topic $=122643.0$

[2] 27.al (2017) "Kur Dashnor Diko nxirrte armë nga deti në vitin 1997". November 18 [online]. Retrieved on February 28, 2019 at http://27.al/kurdashnor-diko-nxirrte-arme-nga-deti-ne-vitin-1997/.

[3] Balkanweb (2016) "Berisha i qëndron deklaratës për armët: Nuk thashë demokratë armatosuni, por qytetarë", April 26. Retrieved online on April 30, 2017 at https://balkanweb.com/berisha-i-qendron-deklarates-per-armetnuk-thashe-demokrate-armatosuni-por-qytetare/.

[4] Balkanweb (2017) “Të dorëzosh armët pa leje përkundrejt një "shpërblimi”? Ja stimuli që propozon deputeti i PS", April 18. Retrieved online on April 30, 2017 at https://balkanweb.com/site/te-dorezosh-armet-pa-lejeperkundrejt-nje-shperblimi-ja-stimuli-qe-propozon-paulin-sterkaj/.

[5] Balkanweb (2017) "VIDEO/ Ish- kryeministri Berisha: Unë hapa depot e armëve për të furnizuar UÇK-në”, April 3. Retrieved online on April 30, 2017 at https://balkanweb.com/video-ish-kryeministri-berisha-une-hapa-depote-armeve-per-te-furnizuar-uck-ne/.

[6] Buzhala, B. (2017) "Kur ra Shqipëria - Pjesa II" (When Albania fell - Part II), Documentary on 1997 events and Kosova war, in Zona Express, TV Dukagjini, April 2, Kosova. Video retrieved online on April 30, 2017, https://www.youtube.com/watch?time_continue $=1110 \& v=N K R 1 \mathrm{Gmh} 3 \mathrm{X} 0 \mathrm{E}$.

[7] Java News (2017) “Deputeti i PS: T’u jepet një laptop atyre që dorëzojnë armët”, April 18. Retrieved online on April 30, 2017 at http://www.javanews.al/deputeti-i-ps-tu-jepet-nje-laptop-atyre-qedorezojne-armet/.

[8] Java News (2017) "Firmosin deputetët/Afati për dorëzimin vullnetar të armëve shtyhet deri në dhjetor", April 18. Retrieved online on April 30, 2017 
at http://www.javanews.al/firmosin-deputetetafati-per-doreziminvullnetar-te-armeve-shtyhet-deri-ne-dhjetor/.

[9] Lajmi.net (2016) "Stresi, shok me të fortin e 'Myslym Shyrit', drogë, armë dhe femra (Foto+18)", 13 th July. Retrieved online on April 30, 2017 at https://lajmi.net/stresi-shok-te-fortin-e-myslym-shyrit-droge-arme-dhefemra-foto18/.

[10] Panorama (2013) “Sterkaj: Armët e'97 të legalizohen, pastaj të mblidhen", February 15. Retrieved online on April 30, 2017 at http://www.panorama.com.al/sterkaj-armet-e-97-te-legalizohen-pastaj-temblidhen/.

[11] Telegrafi (2018) "I inspiruar nga loja e famshme që e luajti në fëmijëri, Stresi flet rreth projektin të ri 'GTA' që do ta sjellë së shpejti" (ft.Hellbanianz), 2 $2^{\text {nd }}$ February.

[12] Tema (2018) “Berisha bën thirrje për luftë: Në sheshet e Shqipërisë do ushtojë 'O djem rrëmebin armët, ja vdekje ja liri”. December 21. Retrieved online on March 10, 2019 at

http://www.gazetatema.net/2018/12/21/video-berisha-ben-thirrje-perlufte-ne-sheshet-e-shqiperise-do-ushtoje-o-djem-rrembeni-armet-ja-vdekjeja-liri/.

[13] The Express (2018) "Albanian drug lords who 'run London' flaunt pictures of guns and wads of cash on Instagram", $2^{\text {nd }}$ November.

[14] The Guardian (2019) "Kings of cocaine: how the Albanian mafia seized control of the UK drugs trade", $13^{\text {th }}$ January.

[15] The Sun (2017) "Jailed Albanian gang members are posting videos online of themselves taking drugs in a British prison", $4^{\text {th }}$ December.

[16] The Sun (2019) "Brutal Mafia. The inside story of how brutal Albanian gangs rose from the UK's premier sex traffickers to kingpin cocaine dealers", $10^{\text {th }}$ March.

\section{SOCIAL MEDIA}

[1] ASP (2017, April) "Vijon masivisisht dorëzimi vullnetar i armëve”, April 4. Policia e Shtetit Official Facebook profile. Retrieved online on April 30, 2017, https://www.facebook.com/1502420603377639/videos/19380294631500 $82 /$.

[2] MOS GJUAJ, por DUAJ (2016). In Facebook, Public Page. Retrieved April 30, 2017, from https://www.facebook.com/MOS-GJUAJ-por-DUAJ$887676457999184 /$

[3] Shqiperia Pa Arme (2017). In Facebook, Public Page. Retrieved April 30, 2017, from https://www.facebook.com/shqiperiapaarme/.

\section{YOUTUBE VIDEOS}

[1] MoI Albanian Ministry of Interior (2017, March) “\#ShqipëriaPaArmë - Spot i bazuar në ngjarje të vërtetë", in YouTube; March 24th. Retrieved 9th March 2019, from https://www.youtube.com/watch?v=HWWUzPe3a6U. (C2017 
Ministria e Brendshme. Supported by PAMECA. Marketing agency Connext. Advertising agency Nilor.

[2] MoI Albanian Ministry of Interior (2017, April) “\#ShqipëriaPaArmë Spoti VIP MPB, 10 prill 2017", in YouTube; April 10 ${ }^{\text {th }}$. Retrieved 9th March 2017, from https://www.youtube.com/watch?v=emN639oTqTs. (C2017 Ministria e Brendshme. Supported by PAMECA. Marketing agency Connext. Advertising agency Nilor. 